\title{
Muscarinic activation of transient inward current and contraction in canine colon circular smooth muscle cells
}

\author{
A. Molleman, L.W.C. Liu, and J.D. Huizinga
}

\begin{abstract}
Muscarinic receptor mediated membrane currents and contractions were studied in isolated canine colon circular smooth muscle cells. Carbachol $\left(10^{-5} \mathrm{M}\right)$ evoked a slow transient inward current that was superimposed by a transient outward current at holding potentials greater than $-50 \mathrm{mV}$. Carbachol contracted the cells by $70 \pm 2 \%$. The effects of carbachol were blocked by atropine $\left(10^{-6} \mathrm{M}\right)$, tetraethyl ammonium $(20 \mathrm{mM})$, and BAPTA-AM $(25 \mathrm{mM}$ applied for $20 \mathrm{~min})$. The inward current and contraction were not sensitive to diltiazem $\left(10^{-5} \mathrm{M}\right)$, nitrendipine $\left(3 \times 10^{-7} \mathrm{M}\right)$, niflumic acid $\left(10^{-5} \mathrm{M}\right)$, or $\mathrm{N}$-phenylanthranilic acid $\left(10^{-4} \mathrm{M}\right)$, but were gradually inhibited after repetitive stimulations in $\mathrm{Ca}^{2+}$ free solution. $\mathrm{Ni}^{2+}(2 \mathrm{mM})$ inhibited the inward current by $67 \pm 4 \%$. The inward current reversed at $+15 \mathrm{mV}$. The outward component could be selectively inhibited by iberiotoxin $(20 \mathrm{nM})$ or by intracellular $\mathrm{Cs}^{+}$. Repeated stimulation in the presence of cyclopiazonic acid (CPA, $3 \mu \mathrm{M})$ inhibited the carbachol-induced outward current and partially inhibited contraction. CPA did not inhibit the inward current. In conclusion, muscarinic receptor stimulation evoked a CPA-sensitive calcium release that caused contraction and a CPA-insensitive transient inward current was activated that is primarily carried by $\mathrm{Ca}^{2+}$ ions and is sensitive to $\mathrm{Ni}^{2+}$.
\end{abstract}

Key words: calcium, carbachol, smooth muscle, cyclopiazonic acid, sarcoplasmic reticulum.

Résumé : On a examiné la contraction et les courants membranaires induits par les récepteurs muscariniques dans des cellules musculaires lisses circulaires isolées de côlons canins. Le carbachol $\left(10^{-5} \mathrm{M}\right)$ a induit un courant entrant transitoire lent auquel s'est ajouté un courant sortant transitoire aux potentiels de maintien supérieurs à $-50 \mathrm{mV}$. Le carbachol a contracté les cellules à $70 \pm 2 \%$. Ses effets ont été bloqués par l'atropine $\left(10^{-6} \mathrm{M}\right)$, le tétraéthylammonium $(20 \mathrm{mM})$ et le BAPTA-AM (25 mM appliqué pendant $20 \mathrm{~min})$. Le courant entrant et la contraction ont été insensibles au diltiazem $\left(10^{-5} \mathrm{M}\right)$, à la nitrendipine $\left(3 \times 10^{-7} \mathrm{M}\right)$, à l'acide niflumique $\left(10^{-5} \mathrm{M}\right)$ ou à $l^{\text {'acide }}$ $\mathrm{N}$-phénylanthranilique $\left(10^{-4} \mathrm{M}\right)$, mais ils ont été graduellement inhibés après des stimulations répétées dans une solution sans $\mathrm{Ca}^{2+}$. Le $\mathrm{Ni}^{2+}(2 \mathrm{mM})$ a inhibé le courant entrant de $76 \pm 4 \%$. Celui-ci a été inversé à $+15 \mathrm{mV}$. Le courant sortant a pu être sélectivement inhibé par l'ibériotoxine $(20 \mathrm{nM})$ ou par le $\mathrm{Cs}^{+}$intracellulaire. Une stimulation répétée en présence d'acide cyclopiazonique (CPA, $3 \mu \mathrm{M})$ a inhibé le courant sortant induit par le carbachol, et partiellement inhibé la contraction, mais n'a pas inhibé le courant entrant. Ainsi, la stimulation des récepteurs muscariniques provoque une libération de calcium sensible au CPA qui déclenche la contraction. De plus, un courant entrant transitoire insensible au CPA, principalement transporté par les ions $\mathrm{Ca}^{2+}$ et sensible au $\mathrm{Ni}^{2+}$, est activé.

Mots clés : calcium, carbachol, musculaires lisses, acide cyclopiazonique, réticulum sarcoplasmique.

[Traduit par la Rédaction]

\section{Introduction}

The motility of most organs of the gastrointestinal tract is influenced by slow waves whose overall characteristics include contributions from the interstitial cells of Cajal (ICC), smooth muscle cells, and nerves. In the canine colon, the slow wave activity originates from the submuscular plexus area of the circular muscle layer (Liu and Huizinga 1993; Durdle et al. 1983; Smith et al. 1987). Stimulation of muscarinic receptors with carbachol or acetylcholine significantly increases the duration and amplitude of these slow waves as well as the amplitude and number of action potentials superimposed on the slow wave plateaus (BarajasLópez and Huizinga 1989; Huizinga et al. 1984). These electrophysiological changes are all associated with an increase in the force of phasic contractions and both are abolished by L-type $\mathrm{Ca}^{2+}$ channel blockers (Barajas-López and Huizinga 1989; Huizinga et al. 1984). Carbachol also depolarizes the resting membrane potential of circular muscle cells from -72 to $-68 \mathrm{mV}$;

Received April 6, 2000. Published on the NRC Research Press web site on December 15, 2000.

A. Molleman, ${ }^{1}$ L.W.C. Liu, and J.D. Huizinga. ${ }^{2}$ Intestinal Disease Research Programme, Department of Medicine, McMaster University, HSC-3N5C, 1200 Main Street West, Hamilton, ON L8N 3Z5, Canada.

${ }^{1}$ Present address: Department of Biosciences, University of Hertfordshire, Hatfield Herts., AL10 9AB, U.K.

${ }^{2}$ Author for correspondence (e-mail: huizinga@mcmaster.ca). 
this depolarization is not abolished by L-type $\mathrm{Ca}^{2+}$ channel blockers. These data suggest that muscarinic receptor stimulation by carbachol evokes two distinct components of the inward current based on sensitivity to L-type $\mathrm{Ca}^{2+}$ channel blockers.

Several studies elucidating the ion channels involved in the muscarinic responses were reviewed by Janssen and Sims (1997). The electrophysiological effects of muscarinic stimulation have been ascribed to the activation of voltagegated $\mathrm{Ca}^{2+}$ channels (Clapp et al. 1987; Yabu et al. 1992), nonspecific cation channels (Benham et al. 1985; Konda et al. 1998; Komori et al. 1998), and chloride channels. Inhibition of $\mathrm{K}^{+}$conductance can also be involved. In isolated cells of canine colonic circular smooth muscle, Cole et al. (1989) demonstrated that acetylcholine markedly inhibits the $\mathrm{Ca}^{2+}$-activated component of the time dependent outward current $\left(\mathrm{gK}_{\mathrm{Ca}}\right)$, a response sensitive to nifedipine. This effect is important in the regulation of excitability. In guinea-pig ileal smooth muscle cells, a biphasic suppression of the voltage-gated $\mathrm{Ca}^{2+}$ channel current through a pertussis toxin insensitive $G$ protein was recently described (Unno et al. 1995). With respect to nonspecific cation channels, superfusion of acetylcholine to canine colonic smooth muscle cells evoked a transient inward current of $35 \mathrm{pA}$, followed by a sustained phase of 9 pA (Lee et al. 1993). The sustained phase was mediated by cation channels permeable to $\mathrm{Na}^{+}$and $\mathrm{Ca}^{2+}$ and blocked by $\mathrm{Ni}^{2+}$. This sustained inward current showed little voltage dependence between -70 and $-20 \mathrm{mV}$. The transient component of the inward current was not characterized in this study. In the guinea-pig jejunal smooth muscle cells, nonspecific cation channels carrying primarily $\mathrm{Na}^{+}$ions were activated as a result of the induced $\mathrm{Ca}^{2+}$ release from intracellular stores following an increase in inositol 1,4,5-triphosphate (Pacaud and Bolton 1991). Similar cation conductances have been described in other small intestine preparations: in guinea-pig ileum smooth muscle cells Konda et al. (1998) showed muscarinic receptor mediated $\mathrm{Ca}^{2+}$ release and cation channel activation by using $\mathrm{Ca}^{2+}$ fluorescence and a perforated patch clamp. There is evidence that there are two receptor subtypes involved in this response (Zholos and Bolton 1997), a phenomenon also seen in guinea-pig colon (Sawyer and Ehlert 1998).

The objective of the current study was to further characterise the transient component of muscarinic receptor mediated inward currents in the colonic smooth muscle. The relationships between transient inward and outward currents, contraction, and intracellularly stored $\mathrm{Ca}^{2+}$ were studied. These experiments were performed by puffing carbachol onto single cells to make the responses rapid and highly reproducible. The inward currents were repeatedly evoked on the same cell, allowing for pharmacological characterization.

\section{Materials and methods}

\section{Cell dispersion}

Mongrel dogs were killed with an iv injection of sodium pentobarbital $(100 \mathrm{mg} / \mathrm{kg})$. The proximal colon was dissected, cut open, and pinned down with the mucosal side up in a dissecting dish containing aerated Krebs solution (see Solutions section). After removing the mucosa and the submucosal layer, the longitudinal muscles with the myenteric plexus were removed. Strips of circular muscle were carefully peeled off from the remaining musculature. The strips were cut into small fragments of $1 \mathrm{~mm}$ in length under a stereo microscope and then brought into a taurinerich $(10 \mathrm{mM})$ extracellular solution (ECS; see Solutions section) with $0.1 \mathrm{mM} \mathrm{Ca}^{2+}$ supplemented with collagenase $(0.25 \mathrm{mg} / \mathrm{mL}$, Blend F), papain $(1.25 \mathrm{mg} / \mathrm{mL})$, bovine albumin $(2 \mathrm{mg} / \mathrm{mL})$, and trypsin inhibitor, Type II-S $(2 \mathrm{mg} / \mathrm{mL})$. These chemicals were obtained from Sigma Chemical Co. (St. Louis, Mo., U.S.A.). The tissue was incubated for $30-45 \mathrm{~min}$ at $37^{\circ} \mathrm{C}$ under gentle rotation. The tissue was then rinsed in ECS. Single cells were released by gentle agitation using a small bore Pasteur pipette. The cells were brought into normal ECS on $3.5 \mathrm{~cm}$ culturing dishes (type 3001, Falcon, Lincoln Park, N.J., U.S.A.) and kept at $4{ }^{\circ} \mathrm{C}$ until use (within $3 \mathrm{~h}$ ). The dispersed cells were elongated, spindle shaped with a bright, smooth appearance under phase contrast optics. Cells selected for experimentation were slightly attached to the culture dish.

\section{Electrophysiology}

Patch pipettes made of $1.5 \mathrm{~mm}$ glass (TW150-6; WP-Instruments, New Haven, Conn., U.S.A.) were pulled on a FlamingBrown puller (Sutter P-80 PC, San Rafael, Calif., U.S.A.). Culturing dishes (fluid volume $3 \mathrm{~cm}^{3}$ ) were placed on a microscope with phasecontrast optics (Zeiss, Germany). Patch clamp measurements were performed at $30^{\circ} \mathrm{C}$ with electrodes (resistance: 1-3 M 2 ) connected through an $\mathrm{Ag} / \mathrm{AgCl}$ junction to the headstage of an Axopatch-1D patch clamp amplifier (Axon Instruments, Foster City, Calif., U.S.A.). Voltage clamp control, data storage, and analysis were performed on a personal computer (Samsung S550) using a TL-1 interface and the software package pClamp (version 5.5.1, Axon Instruments). Signals, monitored on a digital oscilloscope (Nicolet 3091, Madison, Wis., U.S.A.), were filtered through a 1st order low pass filter with a cutoff frequency of $200 \mathrm{~Hz}$, and sampled at $500 \mathrm{~Hz}$. The micropipettes were mounted on a hydraulic micromanipulator (Narashige MO-303, Japan, and Newport MX-530, Fountain Valley, Calif., U.S.A.) to approach the cells.

Carbachol was applied to a single cell by a glass pipette (tip diameter of 1-2 $\mu \mathrm{m}$ ) brought within 1 cell length. Bathing solutions were perfused at $1.5 \mathrm{~mL} / \mathrm{min}$. Carbachol solution was blown ("puffed") onto the cell by pressure ( 2 bar) for $10 \mathrm{~s}$. Constant flow was established within 3 video frames $(\sim 60 \mathrm{~ms})$. This period is neglected in the discussion of response delays. Stimulation was monitored and recorded using a CCD video camera (Hitachi VK-C360, Japan), VCR (JVC HR-DX44U, Japan), and monitor (Mitsubishi AUM 1381A, Japan). Contraction of single cells was measured offline by loading the recorded video images onto a computer with image analysis software and tracing the axes of the cells.

\section{Perforated patch clamp}

The tips of patch pipettes were filled with normal intracellular solution (ICS; see Solutions section) by suction. The rest of the pipette was backfilled with ICS supplemented with $5 \mu \mathrm{L} / \mathrm{mL}$ nystatin stock $(5 \mathrm{mg} / \mathrm{mL}$ DMSO). Approximate liquid junction potentials (LJPs) were calculated using the Henderson liquid junction potential equation (Barry and Lynch 1991), in which ion activities were represented by concentrations. LJPs did not exceed $3.9 \mathrm{mV}$ (for the Cs-ICS-ECS junction). After contact between the cell and the pipette, a gigaohm seal was formed by applying a gentle suction. In the perforated patch experiments (Falke et al. 1989), only cells that showed access resistance lower than $15 \mathrm{M} \Omega$ within 20 min after gigaseal formation were used for experiments. Resting current was set to zero at the start of each experiment. All results are presented as mean $\pm \mathrm{SE}$ ( $n=$ number of experiments).

Repeated stimulation (with $10 \mathrm{~min}$ intervals) occasionally revealed a decrease of the current response (run-down). Therefore, each test-experiment was preceded and followed by a control experiment. Test experiments were compared to with the average of preceding and recovery controls. Recoveries were never lower than $70 \%$ of initial current values. 
Fig. 1. Carbachol-induced currents at different holding potentials. At a holding potential (HP) of $-30 \mathrm{mV}$, the carbachol-induced whole cell current was dominated by an outward current (upward deflection) with a small inward current (downward deflection) in the tail. The inward current became more evident at a holding potential of $-70 \mathrm{mV}$ when the outward current was not activated.

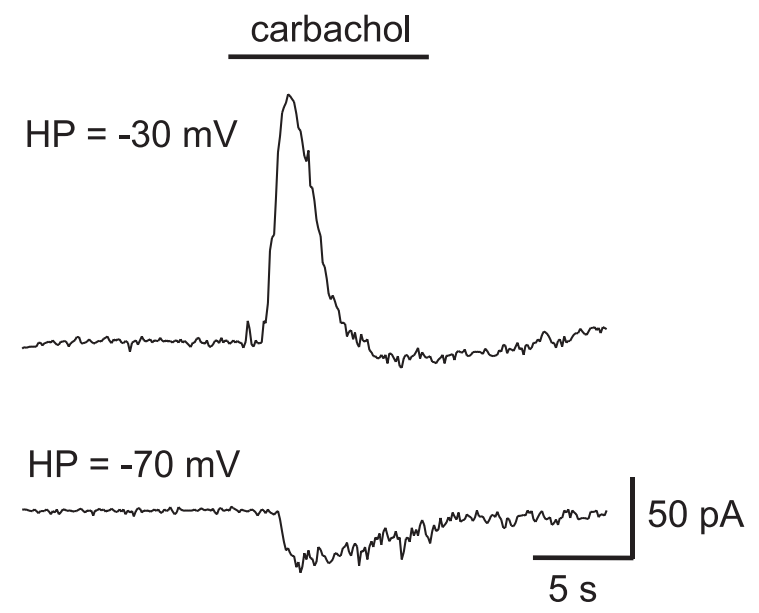

\section{Solutions and drugs}

The composition of the Krebs physiological salt solution was composed of (in mM): $\mathrm{NaCl} 120, \mathrm{KCl} 5.9, \mathrm{CaCl}_{2} 2.5, \mathrm{MgCl}_{2} 1.2$, $\mathrm{NaHCO}_{3} 20, \mathrm{NaH}_{2} \mathrm{PO}_{4}$ 1.2, and glucose 11, equilibrated with $95 \% \mathrm{O}_{2}-5 \% \mathrm{CO}_{2}$ at $\mathrm{pH} 7.3-7.35$. The composition of the standard extracellular solution (ECS) (Molleman et al. 1989) was (in mM): $\mathrm{NaCl} 125, \mathrm{KCl} 6, \mathrm{MgCl}_{2} 2.5, \mathrm{CaCl}_{2}$ 1.2, $\mathrm{NaH}_{2} \mathrm{PO}_{4}$ 1.2, HEPES 10 , and D-glucose-11; pH was set at 7.4 with $\mathrm{NaOH}$. Patch pipettes were filled with intracellular solution (ICS) of the following composition (in $\mathrm{mM}$ ): $\mathrm{KCl} 126, \mathrm{NaCl} 5, \mathrm{MgCl}_{2} 1.2$, HEPES 10 , and D-glucose $11 ; \mathrm{pH}$ was set at 7.2 with $\mathrm{NaOH}$.

Salts were obtained from BDH Inc. (Toronto, Ont., Canada) unless stated otherwise. All drugs were obtained from Sigma Chemical Co. (St. Louis, Mo., U.S.A.), except BAPTA-AM [1,2bis(2-aminophenoxy)-ethane-N,N,N',N'-tetraacetic acid tetrakis (acetoxymethyl ester); Molecular Probes Inc., Eugene, Oreg., U.S.A.], iberiotoxin (a gift from Dr. T. Jones, Peptide Institute, Osaka, Japan), and N-phenylanthranilic acid (Aldrich Chemical Company, Milwaukee, Wis., U.S.A.).

\section{Results}

\section{Carbachol-induced currents}

The dispersion process yielded fibre-shaped cells with a membrane capacitance of $67 \pm 3 \mathrm{pF}$; the average cell length at the beginning of experiments was $405 \pm 17 \mu \mathrm{m}(n=29)$. Puffing of ECS supplemented with $10^{-5} \mathrm{M}$ carbachol onto the cells for $10 \mathrm{~s}$ evoked an inward current at holding potentials less than $-50 \mathrm{mV}$ (Fig. 1). Puffing of ECS without carbachol did not provoke a response $(n=3)$. An outward current superimposed on the inward current was observed at holding potentials greater than $-50 \mathrm{mV}$ (Fig. 1). All responses (including contractions) were abolished by the muscarinic antagonist atropine $\left(10^{-6} \mathrm{M}\right)(n=5)$. The nonspecific $\mathrm{K}^{+}$channel blocker tetraethyl ammonium (TEA, $20 \mathrm{mM}$ ) also abolished all responses (including contractions) to carbachol $(n=4)$.
Fig. 2. Effect of iberiotoxin (IbTX) on the outward current evoked by carbachol. IbTX (20 nM) abolished approximately $80 \%$ of the outward component of the carbachol-induced current at a holding potential of $-40 \mathrm{mV}$. IbTX was perfused into the tissue chamber.
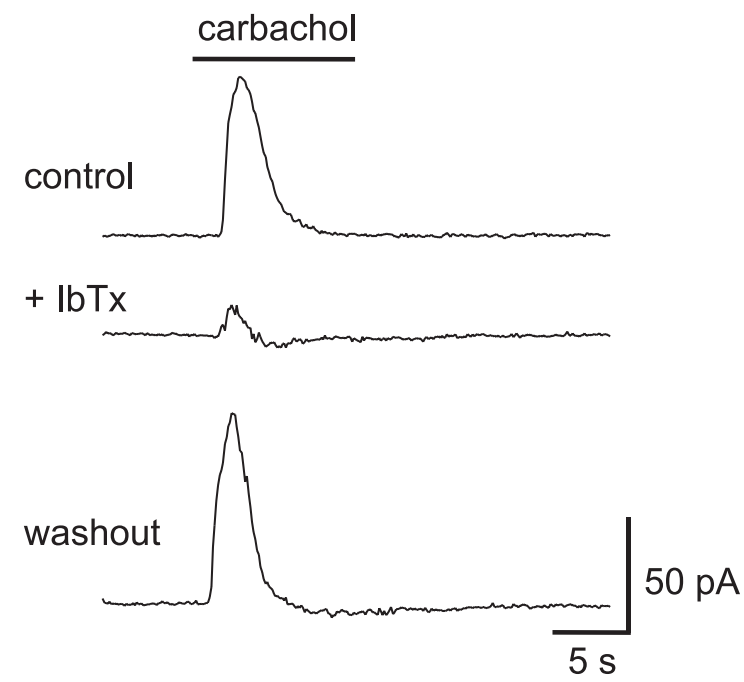

\section{Carbachol-induced outward current}

When holding potentials were greater than $-50 \mathrm{mV}$, the carbachol-induced response was dominated by an outward current (Fig. 1). Iberiotoxin (IbTX, $20 \mathrm{nM}$ ), a blocker of large conductance $\mathrm{Ca}^{2+}$-dependent $\mathrm{K}^{+}$channels, inhibited the carbacholinduced outward current by $81 \pm 3 \%$ ( $n=3$, Fig. 2$)$. When the outward current was evoked by depolarisation, activation started between -30 and $-25 \mathrm{mV}$ and was inhibited by IbTX $(20 \mathrm{nM})$, indicating that the $\mathrm{Ca}^{2+}$-dependent $\mathrm{K}^{+}$conductance could be activated by either muscarinic receptor stimulation or by depolarisation (Fig. 3). The effects of IbTX were completely reversible upon washouts (Figs. 2 and 3).

The onset of the outward current had a delay of more than $1.8 \mathrm{~s}$ after carbachol reached the cells, suggesting involvement of a second messenger system. If $\mathrm{Ca}^{2+}$ released from internal stores evoked the carbachol-induced outward current, pharmacological interference with $\mathrm{Ca}^{2+}$ stores would affect the outward current. CPA $(3 \mu \mathrm{M})$, a specific blocker of the sarcoplasmic reticulum (SR) $\mathrm{Ca}^{2+}$ pump, inhibited the carbachol-induced outward current and completely prevented a response from the second stimulation with carbachol ( $n=7$, Fig. 4, left-hand panels). Caffeine (up to $1 \mathrm{mM}$ ) did not have any effect on carbachol-induced currents.

Because the blockade of outward current by CPA could be due to either reduction of the amount of $\mathrm{Ca}^{2+}$ being released or a direct effect on $\mathrm{Ca}^{2+}$-dependent $\mathrm{K}^{+}$conductance, the effect of CPA on this conductance was investigated. A CPA $(3 \mu \mathrm{M})$ did not inhibit but rather slightly enhanced the $\mathrm{Ca}^{2+}$ dependent $\mathrm{K}^{+}$current evoked by voltage activation (Fig. 5), indicating that the abolition of the current was not a result of a direct blockade of the $\mathrm{Ca}^{2+}$-dependent $\mathrm{K}^{+}$conductance by CPA. The chelation of cytosolic $\mathrm{Ca}^{2+}$ by BAPTA/AM ( $25 \mathrm{mM}$ for $20 \mathrm{~min}$ ) completely abolished the outward current in the first carbachol challenge; this is consistent with 
Fig. 3. Effects of iberiotoxin (IbTX) on the voltage activated outward current. When the outward current was evoked by membrane depolarisation, IbTX $(20 \mathrm{nM})$ reversibly inhibited the whole cell outward current. The increment of voltage steps was $5 \mathrm{mV}$ starting from $-50 \mathrm{mV}$; holding potential was $-70 \mathrm{mV}$.

(A) Current traces in response to depolarising voltage steps. (B) Relationship between membrane potential and peak outward current. The graph shows the average response of 4 experiments.

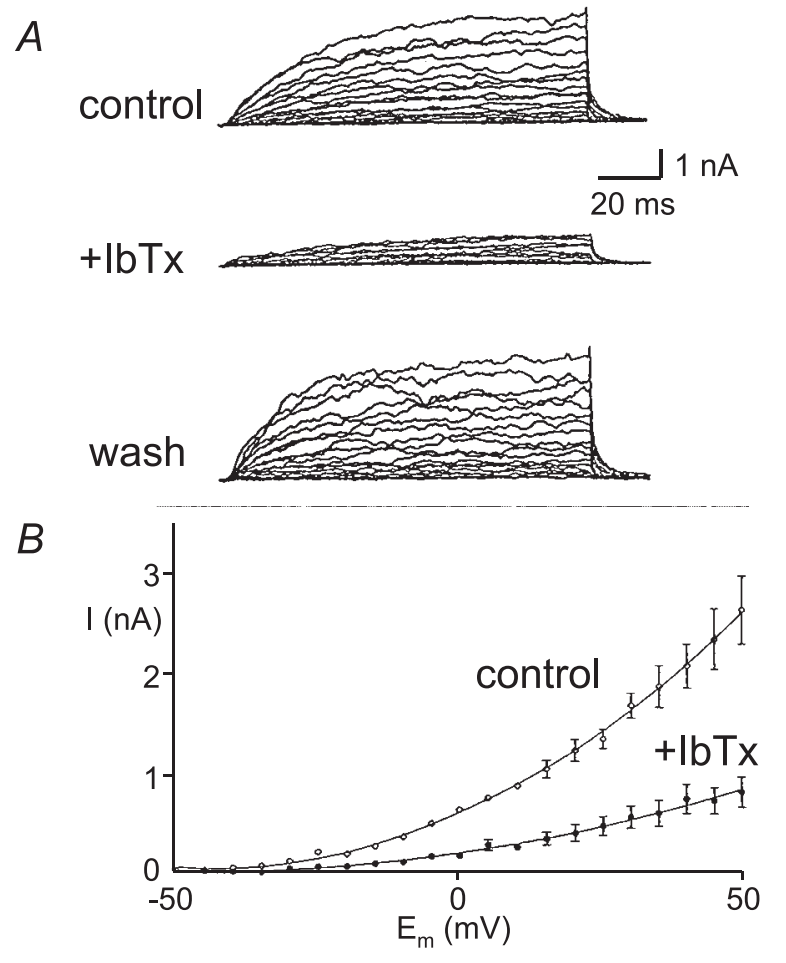

the idea that cytosolic $\mathrm{Ca}^{2+}$ is critical for the activation of $\mathrm{Ca}^{2+}$ dependent $\mathrm{K}^{+}$conductance. Furthermore, repetitive stimulations with carbachol after omission of extracellular $\mathrm{Ca}^{2+}$ (replaced with $1 \mathrm{mM}$ EGTA) progressively reduced the outward current $(n=8)$.

\section{Carbachol-induced inward current}

At a holding potential of $-70 \mathrm{mV}$, puffing $10^{-5} \mathrm{M}$ carbachol for $10 \mathrm{~s}$ evoked a transient inward current of $20 \pm$ $4 \mathrm{pA}$ that was $4-7 \mathrm{~s}$ in duration $(n=28)$. The onset of the current had a delay of $1.7 \pm 0.2 \mathrm{~s}$ from the time of stimulation.

The inward current became more apparent when the outward component of the carbachol-induced responses was abolished by $\mathrm{Cs}^{+}$(Fig. 6), and could be seen from holding potentials of $-90 \mathrm{mV}$ to $0 \mathrm{mV}$. The characteristics of the inward current were not significantly different at holding potentials of -40 or $-70 \mathrm{mV}$. Because current run-down was observed in some cells, ramp protocols were applied during carbachol stimulations to obtain the I-V relationship. Voltage steps to $-90 \mathrm{mV}$ or $+50 \mathrm{mV}(200 \mathrm{~ms})$ were followed by ramps to +50 or $-90 \mathrm{mV}$ (800 ms), respectively. Ramps recorded in the absence of carbachol were subtracted from those recorded in the same cells at the peak of the carbacholinduced inward current to isolate the carbachol effect. The
Fig. 4. Effects of cyclopiazonic acid (CPA) on carbachol-induced currents and contraction. Bar indicates carbachol being puffed onto the cell. Holding potential was $-40 \mathrm{mV}$. (A) Control response, (B) first response in CPA $(3 \mu \mathrm{M}),(\mathrm{C})$ second response in CPA, and (D) washout. Time between stimulations: 1-2, 20 min; 2-3, 10 min; 3-4, 20 min. Left-hand panels show membrane current. Downward deflection denotes inward current. Right-hand panels show the contractile response to carbachol. Cell length is relative to the initial length at $t=0$ for each stimulation.
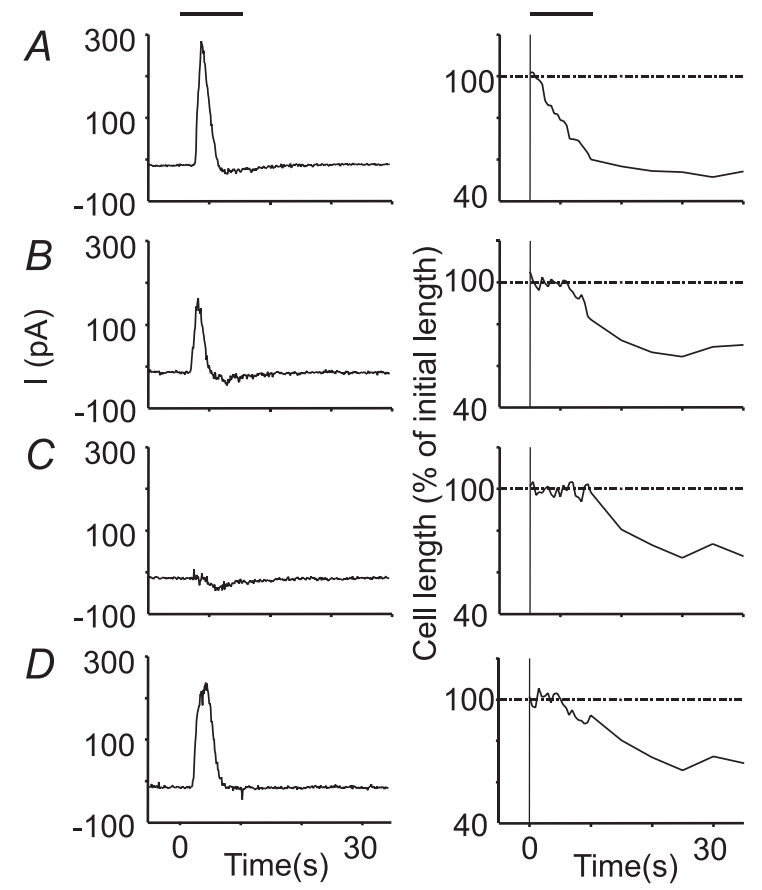

inward current showed a strong outward rectification at potentials between -20 and $50 \mathrm{mV}$ and reversed at $15 \mathrm{mV}(n=$ 4, Fig. 7).

Removal of extracellular $\mathrm{Ca}^{2+}$ in the presence of $0.1 \mathrm{mM}$ EGTA inhibited the inward current by $92 \pm 4 \%(n=8$, Fig. 8A). In 5 experiments, the current was completely abolished. No significant reduction in amplitude of the inward current was observed in subsequent carbachol challenges if the inward current was not completely abolished in the first challenge. The inward current was not significantly modified by substituting extracellular $\mathrm{Na}^{+}$for glucamine $(n=4)$.

The inward current was not sensitive to the L-type $\mathrm{Ca}^{2+}$ channel blockers diltiazem $\left(10^{-5} \mathrm{M}, n=4\right.$, Fig. 8) and nitrendipine ( $\left.3 \times 10^{-7} \mathrm{M}, n=3\right)$, nor to the $\mathrm{Cl}^{-}$channel blockers niflumic acid $\left(10^{-5} \mathrm{M}, n=3\right)$ and N-phenylanthranilic acid $\left(10^{-4} \mathrm{M}, n=3\right) . \mathrm{Ni}^{2+}(2 \mathrm{mM})$, a nonspecific cation channel blocker, reversibly inhibited the inward current by $67 \pm 4 \%(n=3$, Fig. 8B $)$.

To investigate the role of $\mathrm{Ca}^{2+}$ released from internal stores in the generation of the inward current, the effects of CPA $(3 \mu \mathrm{M})$, caffeine (1 mM), and BAPTA were studied. In 6 out of 8 experiments, CPA did not affect the inward current (Fig. 6). In the remaining 2 experiments, the inward current was reversibly prolonged by approximately $35 \%$ at a holding potential of $-70 \mathrm{mV}$. Caffeine $(1 \mathrm{mM})$ did not affect the inward current $(n=3)$, but BAPTA, a cytosolic $\mathrm{Ca}^{2+}$ 
Fig. 5 Effect of cyclopiazonic acid (CPA) on the voltage activated outward current. CPA $(3 \mu \mathrm{M})$ slightly increased the outward current evoked by voltage-step stimulations at room temperature. The increment of voltage steps was $5 \mathrm{mV}$ starting from $-50 \mathrm{mV}$; holding potential was $-70 \mathrm{mV}$. (A) Current traces in response to depolarising voltage steps. Upward deflection denotes outward current. (B) Relationship between membrane potential and peak current drawn from graph (A).
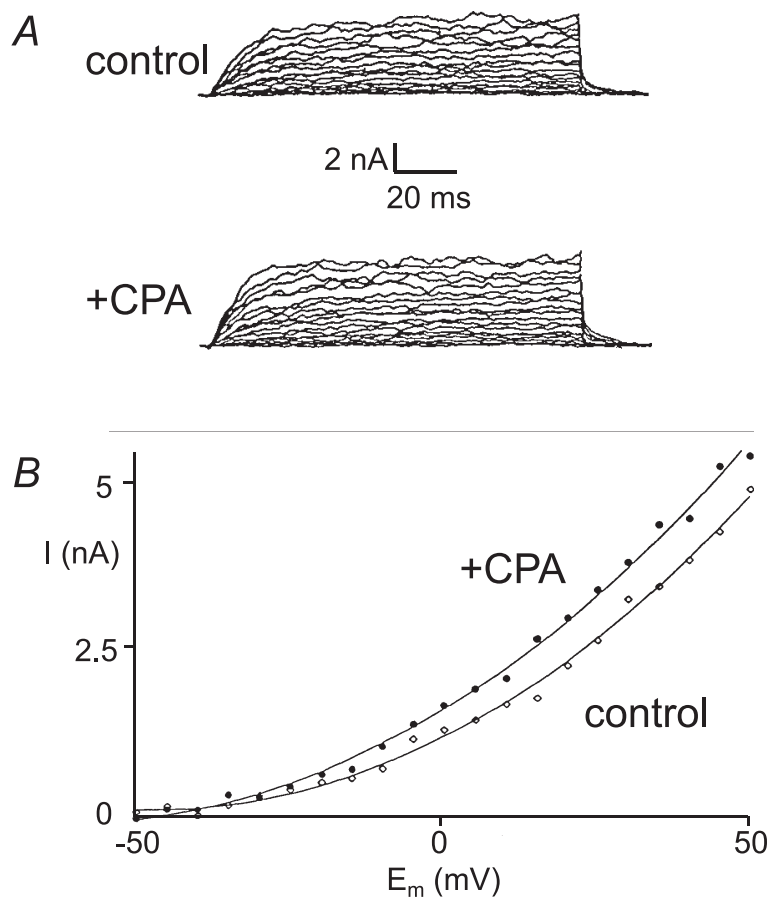

chelator, loaded as BAPTA/AM at a bathing concentration of $25 \mathrm{mM}$ for $20 \mathrm{~min}$, completely abolished the inward current in the first carbachol challenge ( $n=2$, data not shown).

\section{Carbachol-induced contraction}

Puffing carbachol onto the cells induced contractions which shortened them to $70.4 \pm 2.2 \%(n=35)$ of their initial length. Cells recovered $82 \pm 3 \%(n=16)$ of their initial length after 5 min (Figs. 9 and 10). Subsequent stimulations evoked contractions of the same amplitude $(70 \pm 2 \%, n=$ 16), with cells recovering $87 \pm 3 \%$ of their initial length. The onset of contraction had a delay of $1.9 \pm 0.5 \mathrm{~s}(n=35)$ from the time point of stimulations. Contraction occurred over the full experimental potential range $(-120$ to $-30 \mathrm{mV})$, with little change in amplitude. The magnitude of the cell shortening induced by carbachol was independent of the holding potentials (Fig. 2), however, this was tested in only one cell. The onset of the contraction had a delay of more than $1.8 \mathrm{~s}$ after carbachol reached the cells, similar to the carbachol-induced currents. However, unlike the currents, contractions were not affected by CPA $(3 \mu \mathrm{M})(n=7$, Fig. 4 , right-hand panels). Caffeine (up to $1 \mathrm{mM}$ ) did not have any effect on carbachol-induced contractions.

Substitution of extracellular $\mathrm{Ca}^{2+}$ for EGTA only blocked contraction after repetitive stimulations. BAPTA/AM (25 $\mathrm{mM}$ for $20 \mathrm{~min}$ ) abolished contraction in the first carbachol challenge. Addition of CPA $(3 \mu \mathrm{M})$ caused an im-
Fig. 6. Cesium specifically abolished the outward component of the carbachol-induced current. Replacing $\mathrm{K}^{+}$for $\mathrm{Cs}^{+}$in the patch-pipette solution completely abolished the outward component of the carbachol-induced current as noted at a holding potential (HP) of $-40 \mathrm{mV}$ (compare with Fig. 1). When $\mathrm{Cs}^{+}$ abolished the outward current, the inward current evoked by carbachol was not different at a holding potential of either -70 $\mathrm{mV}$ or $-40 \mathrm{mV}$.
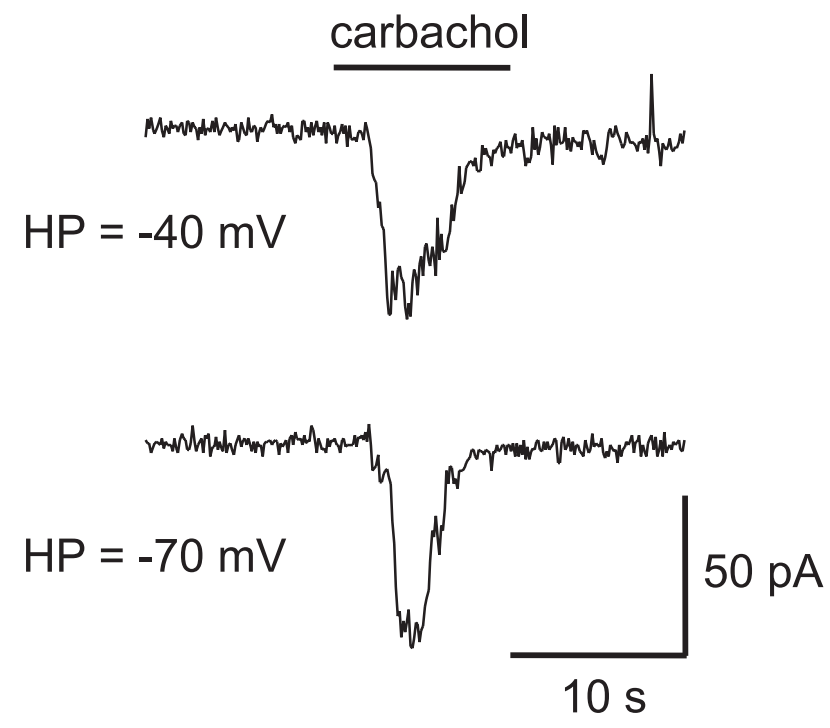

Fig. 7. Voltage ramp response of the carbachol-induced inward current. When the outward component was abolished by substituting $\mathrm{K}^{+}$in the pipette solution for $\mathrm{Cs}^{+}$, the $\mathrm{I}-\mathrm{V}$ relationship, as revealed by a ramp protocol, of the inward current showed a strong rectification at potentials positive of $-20 \mathrm{mV}$. Downward deflection denotes inward current. The carbachol-induced inward current reversed at $+15 \mathrm{mV}$.

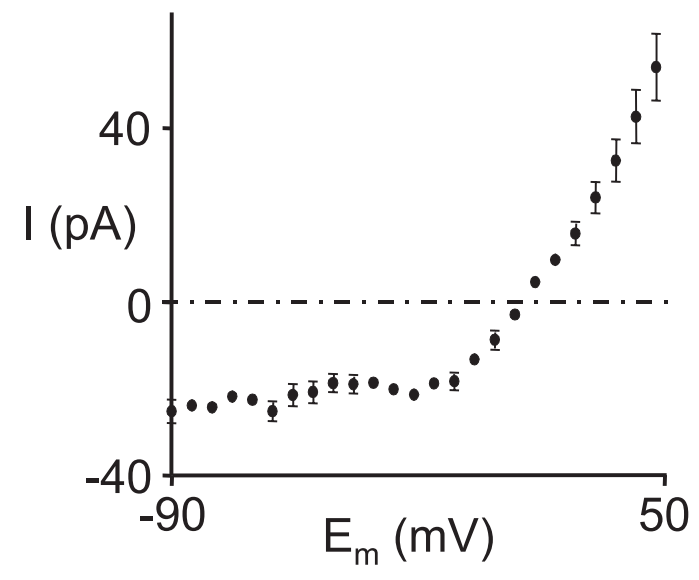

mediate abolishment of the initial part of the contraction. The delay of the onset of contraction was increased up to $7 \mathrm{~s}$ $(n=7)$. The carbachol-induced contractions were not blocked by the L-type $\mathrm{Ca}^{2+}$ channel blockers diltiazem $\left(10^{-5}\right.$ $\mathrm{M}, n=4)$ and nitrendipine $\left(3 \times 10^{-7} \mathrm{M}, n=3\right) . \mathrm{Ni}^{2+}(2 \mathrm{mM})$ did not significantly affect the carbachol-induced contraction. 
Fig. 8. Effects of manipulating access of the cell to extracellular $\mathrm{Ca}^{2+}$. Holding potential was $-70 \mathrm{mV}$. (A) Effect of addition of EGTA to the bathing solution on the carbachol-induced inward current. ECS, without $\mathrm{CaCl}_{2}$ and with addition of $0.1 \mathrm{mM}$ EGTA, was perfused to the tissue chamber for $5 \mathrm{~min}$ before carbachol stimulation. Carbachol failed to evoke an inward current. This effect was reversible. (B) Carbachol-induced inward current in the presence of diltiazem and $\mathrm{Ni}^{2+}$. Diltiazem $(10 \mathrm{mM})$ did not affect the carbachol-induced inward current. In the same cell, perfusion of $2 \mathrm{mM} \mathrm{Ni}^{2+}$ completely abolished the carbachol-induced inward current.

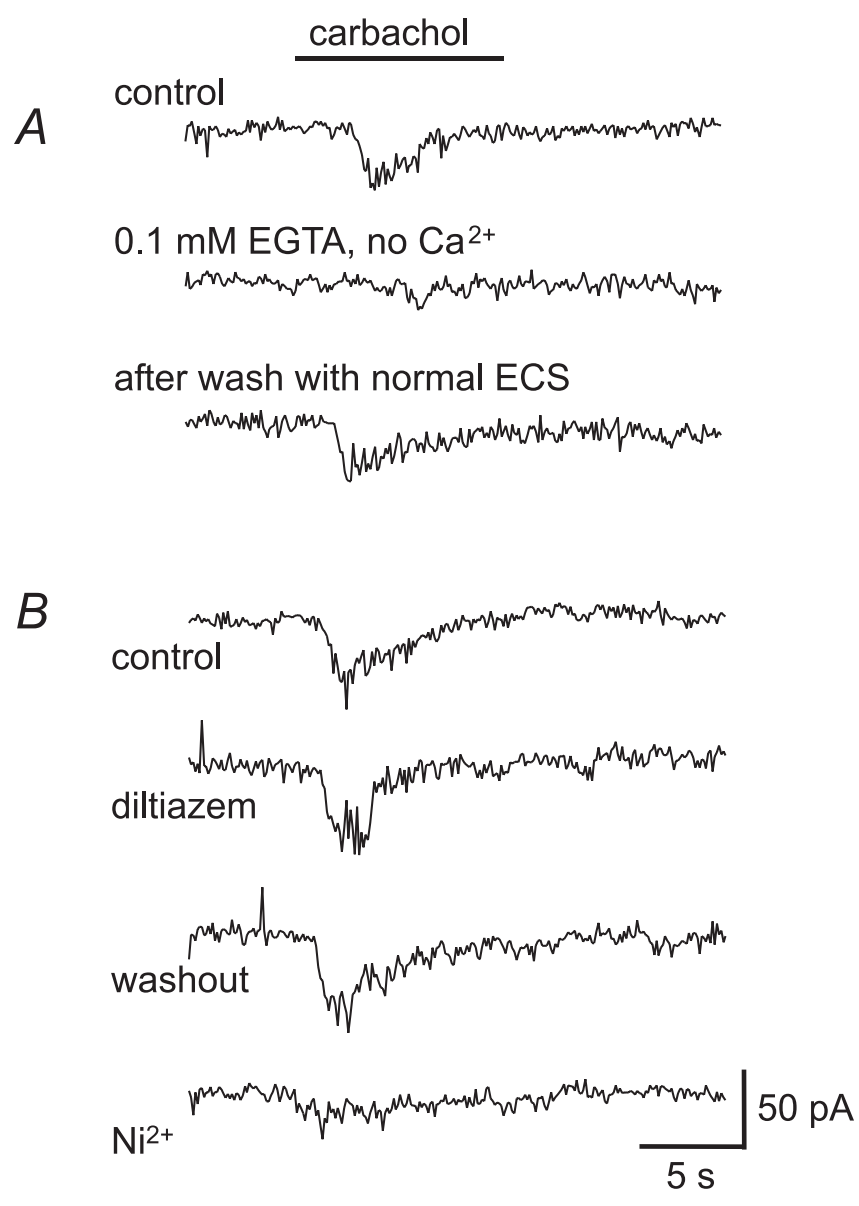

\section{Discussion}

This study shows for the first time carbachol-induced inward currents and their correlation with contractions in canine colonic circular muscle cells. It complements a previous study that described an inward current composed of a transient and a sustained phase activated by acetylcholine (Lee et al. 1993). Our study further characterises the transient component of the inward current. It demonstrates that a CPA-sensitive $\mathrm{Ca}^{2+}$ store is involved in the muscarinic response. Upon carbachol stimulation, the $\mathrm{Ca}^{2+}$ released from the SR induced transient activation of an outward current and contraction in smooth muscle cells. All responses were blocked by atropine, suggesting that muscarinic receptors mediated the effects of carbachol. Tetraethyl ammonium also
Fig. 9. Contractile response to carbachol at different holding potentials. Carbachol was puffed onto a cell for $10 \mathrm{~s}$ at $t=0$. Cell length is presented as percentage of the initial cell length.

$\bullet,-130 \mathrm{mV} ; \triangle,-100 \mathrm{mV} ;+,-70 \mathrm{mV} ; \square,-30 \mathrm{mV}$. (A) Linear time scale. (B) Log time scale for better visualisation of the delay in onset of the contraction.

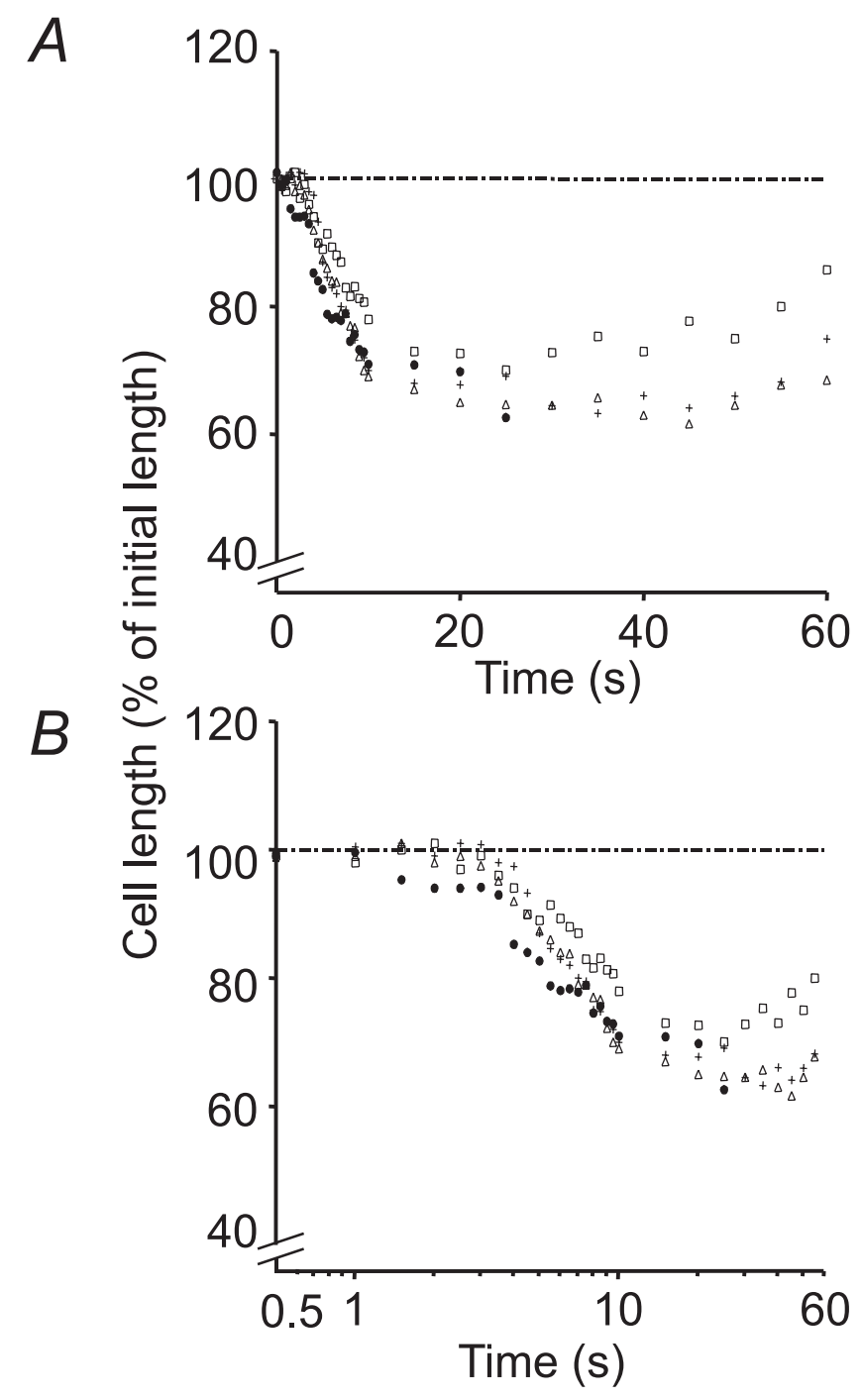

blocked all responses, suggesting that it affects receptor signalling at the concentration used $(20 \mathrm{mM})$.

\section{Carbachol-evoked calcium release from the sarcoplasmic reticulum}

Within 1.2-2 s after exposure of the muscarinic receptors to carbachol, the smooth muscle cells contracted as a consequence of $\mathrm{Ca}^{2+}$ released from the SR. In the presence of L-type calcium channel blockers and in the absence of extracellular $\mathrm{Ca}^{2+}$, we showed that carbachol can still evoke marked contraction of the circular muscle cells and decrease the cell length to $70 \%$ of its initial length. CPA, a blocker of the SR calcium pump in this tissue (Liu et al. 1995), inhibited contractile activity. Carbachol-induced contractions were gradually inhibited when extracellular $\mathrm{Ca}^{2+}$ was replaced by 
Fig. 10. Single cell contractile response to multiple carbachol challenges. Cell length is presented as a percentage of the initial cell length at the beginning of each carbachol stimulation. Carbachol reaches the cell at $t=0$. Holding potential was $-70 \mathrm{mV}$. $\square$, first stimulation; +, second stimulation (after $10 \mathrm{~min}$ interval). (A) Linear time scale. (B) Log time scale to show the latency of the response.

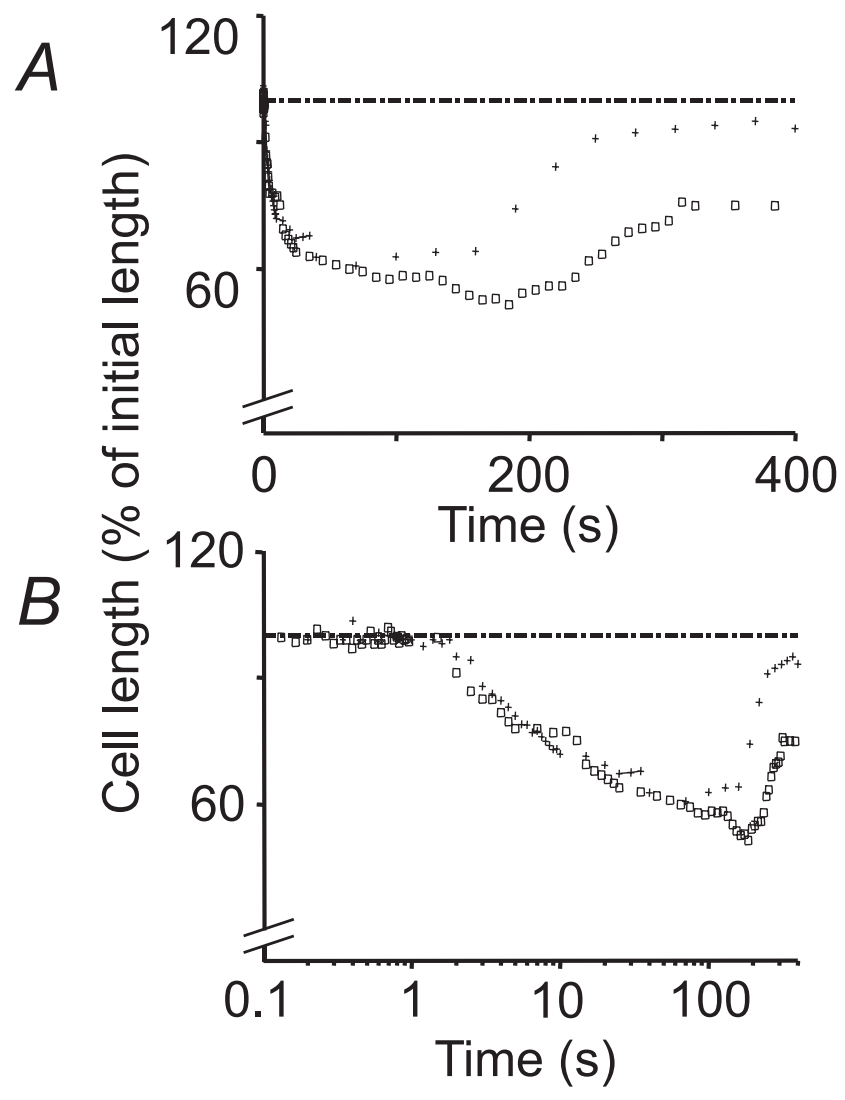

EGTA. This suggests that refilling of the CPA-sensitive stores requires replenishment from extracellular $\mathrm{Ca}^{2+}$ sources. These data indicate that although pharmacological experiments on tissue suggest that contractions evoked by muscarinic stimulation are primarily mediated by L-type calcium channels, the smooth muscle cells are capable of contracting through intracellular calcium release upon muscarinic stimulation.

The hypothesis that carbachol did cause $\mathrm{Ca}^{2+}$ release from the SR was substantiated by the observation that carbachol activated large conductance $\mathrm{Ca}^{2+}$-activated $\mathrm{K}^{+}$channels. Carbachol activated an outward current with an amplitude of $\sim 200 \mathrm{pA}$ at a holding potential of $-40 \mathrm{mV}$ that was inhibited by iberiotoxin. In contrast, the threshold for voltage activation of a $\mathrm{Ca}^{2+}$-activated $\mathrm{K}^{+}$channel was between -30 and $-25 \mathrm{mV}$. It is likely that the increase in cytosolic $\mathrm{Ca}^{2+}$ during carbachol stimulation shifted the activation threshold of the $\mathrm{Ca}^{2+}$-activated $\mathrm{K}^{+}$channels to a lower voltage. The carbachol-induced $\mathrm{Ca}^{2+}$-activated $\mathrm{K}^{+}$current was consistently inhibited in a time dependent manner after a blockade by CPA of $\mathrm{Ca}^{2+}$ uptake into the SR. CPA did not directly inhibit the voltage activated $\mathrm{Ca}^{2+}$-activated $\mathrm{K}^{+}$channels. Similarly, in isolated smooth muscle cells of rabbit small intestine, activation of $\mathrm{Ca}^{2+}$-activated $\mathrm{K}^{+}$channels was observed subsequent to calcium influx through opening of nonspecific cation channels upon induced calcium release from internal stores (Bolton and Lim 1989).

\section{Carbachol-induced transient inward current}

Puffing carbachol onto circular smooth muscle cells for $10 \mathrm{~s}$ evoked a transient inward current of 4-7 s in duration with a delay of $1.7 \mathrm{~s}$. This current was not affected by L-type calcium channel blockers nor by $\mathrm{Cl}^{-}$channel blockers. It was very sensitive to the removal of extracellular $\mathrm{Ca}^{2+}$ but not $\mathrm{Na}^{+}$. Alternatively, the method to remove extracellular $\mathrm{Ca}^{2+}$ (addition of EGTA) could have depleted intracellular $\mathrm{Ca}^{2+}$. However, contractions were only inhibited by this procedure after repeated challenges, suggesting that the immediate inhibition of the carbachol-induced inward current was due to the absence of extracellular $\mathrm{Ca}^{2+}$. This was confirmed by our observation that $\mathrm{Ni}^{2+}$ ions, applied extracellularly, had the same effect. This current, therefore, appears to be rather selective to $\mathrm{Ca}^{2+}$. Thus, the ion selectivity of the channels mediating the transient inward current is different from that of the sustained component of the inward current evoked by muscarinic stimulation. The sustained component is mediated by a non-selective cation channel that does not discriminate between $\mathrm{Ca}^{2+}$ and $\mathrm{Na}^{+}$(Lee et al. 1993). Muscarinic receptor mediated cation channels that are permeable to $\mathrm{Ca}^{2+}$ are also found in bovine ciliary muscle cells (Takai et al. 1997). It is likely that both the transient and the sustained components of the inward current contribute to the contraction along with the depolarization associated with muscarinic stimulation. The relationship between the contraction and inward current was not evident over the voltage range investigated $(-130$ to $-30 \mathrm{mV})$; the driving force for $\mathrm{Ca}^{2+}$ is still substantial at the greatest potential $(-30 \mathrm{mV})$ and the involvement of a $\mathrm{Ca}^{2+}$ pool could result in indirect coupling between the current and contraction. The cation channel mediating the carbachol-induced transient inward current could be coupled to the receptor through the diacylglycerol (DAG) pathway. This type of channel activation was demonstrated in bovine airway smooth muscle (Kajita and Yamaguchi 1993) and rabbit portal vein (Oike et al. 1993).

The carbachol-induced inward current, carried mainly by $\mathrm{Ca}^{2+}$, could serve as a calcium source to fill the SR. Because this carbachol-induced transient inward current is not sensitive to L-type calcium channel blockers and refilling of the $\mathrm{SR}$ requires replenishment from extracellular sources, it is likely that $\mathrm{Ca}^{2+}$ influx through the cation channels, activated by carbachol stimulation, is a $\mathrm{Ca}^{2+}$ source for refilling the $\mathrm{SR}$. Interestingly, the duration of the inward current is prolonged in the presence of CPA when the SR calcium refilling is retarded. It is known that depletion of intracellular $\mathrm{Ca}^{2+}$ stores can promote $\mathrm{Ca}^{2+}$ influx (Bourreau et al. 1991; Van Breemen and Saida 1989; Shuttleworth and Thompson 1992; Randriamampita and Tsien 1993; Clapham 1993). In the A7r5 smooth muscle cells, $10 \mathrm{mM}$ of verapamil could not block the $\mathrm{Ca}^{2+}$ influx (Missiaen et al. 1990), indicating that the filling state of the $\mathrm{IP}_{3}$-sensitive $\mathrm{Ca}^{2+}$ store regulates the entry of $\mathrm{Ca}^{2+}$ through a pathway different from voltageoperated $\mathrm{Ca}^{2+}$ channels. 


\section{A proposed mechanism for the effects of muscarinic stimulation}

Contraction of colonic smooth muscle through stimulation of muscarinic receptors has primarily been studied in tissue and is related to the induction of action potentials and changes in slow wave duration; these effects are mediated by the activation of L-type calcium channels. Using single isolated smooth muscle cells, additional mechanisms of contraction generation have been revealed. Carbachol stimulates syntheses of $\mathrm{IP}_{3}$ and diacylglycerol (DAG) (Zhang and Buxton 1991) as observed in other smooth muscle cells (Ozaki et al. 1992). $\mathrm{IP}_{3}$ can promote $\mathrm{Ca}^{2+}$ release from the SR through activation of the $\mathrm{IP}_{3}$-sensitive $\mathrm{Ca}^{2+}$ channels in the SR membrane. The released $\mathrm{Ca}^{2+}$ causes smooth muscle cells to contract and activates large conductance $\mathrm{Ca}^{2+}$-activated $\mathrm{K}^{+}$channels. In addition, a transient and a sustained inward current are concomitantly evoked. These inward currents can depolarise the cells, prolong the slow wave duration, and contribute directly to generation of contraction. Furthermore, when muscarinic stimulation is longer than 3 min, the large conductance $\mathrm{Ca}^{2+}$-activated $\mathrm{K}^{+}$channels begin to be inactivated (Cole et al. 1989); this inactivation is mediated by a $\mathrm{G}$ protein (Cole and Sanders 1989). Blockade of the large conductance $\mathrm{Ca}^{2+}$-activated $\mathrm{K}^{+}$channels will further lengthen the slow wave duration and increase spiking activity superimposed on the plateaus, leading to an increase in the force of phasic contractions.

Compared with most other non-selective cation channels activated by muscarinic receptor stimulation, the sustained component in canine colon smooth muscle is typical in its $\mathrm{Na}^{+}$permeability (Lee et al. 1993). The transient inward component studied in the present paper is rather unique in its selectivity for $\mathrm{Ca}^{2+}$, although muscarinic receptor activated cation channels permeable to $\mathrm{Ca}^{2+}$ have been observed in other preparations (Takai et al. 1997). We suggest that the cation current could play a role in maintenance of the cell's ability to contract after repeated stimulations. This is a refinement of the postulation that muscarinic activation of non-selective cation channels initiates a positive feedback loop where an increase in intracellular calcium promotes depolarization allowing for activation of voltage-dependent $\mathrm{Ca}^{2+}$ channels (Janssen and Sims 1997).

\section{Acknowledgements}

The authors wish to thank Dr. S.M. Sims from the University of Western Ontario for constructive discussion and valuable technical advice. The Medical Research Council of Canada provided operating grants and an MRC Scientist Award to J.D.H. and a studentship to L.W.C. L.

\section{References}

Barajas-López, C., and Huizinga, J.D. 1989. Different mechanisms of contraction generation in circular muscle of canine colon. Am. J. Physiol. 256: G570-G580.

Barry, P.H., and Lynch, J.W. 1991. Liquid junction potentials and small cell effects in patch-clamp analysis [Review]. J. Membr. Biol. 121: 101-117.

Benham, C.D., Bolton, T.B., and Lang, R.J. 1985. Acetylcholine activates an inward current in single mammalian smooth muscle cells. Nature (London), 316: 345-347.

Bolton, T.B., and Lim, S.P. 1989. Properties of calcium stores and transient outward currents in single smooth muscle cells of rabbit intestine. J. Physiol. 409: 385-401.

Bourreau, J.P., Abela, A.P., Kwan, C.Y., and Daniel, E.E. 1991. Acetylcholine $\mathrm{Ca}^{2+}$ stores refilling directly involves a dihydropyridine-sensitive channel in dog trachea. Am. J. Physiol. 261: C497-C505.

Clapham, D.E. 1993. A mysterious new influx factor? Nature (London), 364: 763-764.

Clapp, L.H., Vivaudou, M.B., Walsh, J.V., Jr., and Singer, J.J. 1987. Acetylcholine increases voltage-activated $\mathrm{Ca}^{2+}$ current in freshly dissociated smooth muscle cells. Proc. Natl. Acad. Sci. U.S.A. 84: 2092-2096.

Cole, W.C., and Sanders, K.M. 1989. G proteins mediate suppression of $\mathrm{Ca}^{2+}$-activated $\mathrm{K}$ current by acetylcholine in smooth muscle cells. Am. J. Physiol. 257: C596-C600.

Cole, W.C., Carl, A., and Sanders, K.M. 1989. Muscarinic suppression of $\mathrm{Ca}^{2+}$-dependent $\mathrm{K}$ current in colonic smooth muscle. Am. J. Physiol. 257: C481-C487.

Durdle, N.G., Kingma, Y.J., Bowes, K.L., and Chambers, M.M. 1983. Origin of slow waves in the canine colon. Gastroenterology, 84: 375-382.

Falke, L.C., Gillis, K.D., Pressel, D.M., and Misler, S. 1989. 'Perforated patch recording' allows long-term monitoring of metabolite-induced electrical activity and voltage-dependent $\mathrm{Ca}^{2+}$ currents in pancreatic islet B cells. FEBS Lett. 251: 167-172.

Huizinga, J.D., Chang, G., Diamant, N.E., and El-Sharkawy, T.Y. 1984. Electrophysiological basis of excitation of canine colonic circular muscle by cholinergic agents and substance P.J. Pharmacol. Exp. Ther. 231: 692-699.

Janssen, L.J., and Sims, S.M. 1997. Muscarinic regulation of ion channels in smooth muscle. In Cellular aspects of smooth muscle function. Edited by C.Y. Kao and M.E. Carsten. Cambridge University Press, Cambridge, U.K. pp. 132-168.

Kajita, J., and Yamaguchi, H. 1993. Calcium mobilization by muscarinic cholinergic stimulation in bovine single airway smooth muscle. Am. J. Physiol. 264: L496-L503.

Kohda, M., Komori, S., Unno, T., and Ohashi, H. 1998. Carbacholinduced oscillations in membrane potential and $\left[\mathrm{Ca}^{2+}\right]_{\mathrm{i}}$ in guinea-pig ileal smooth muscle cells. J. Physiol. 511: 559-571.

Komori, S., Unno, T., Nakayama, T., and Ohashi, H. 1998. $\mathrm{M}_{2}$ and $\mathrm{M}_{3}$ muscarinic receptors couple, respectively with activation of cation channels and potassium channels in intestinal smooth muscle cells. Jpn. J. Pharmacol. 76: 213-218.

Lee, H.K., Bayguinov, O., and Sanders, K.M. 1993. Role of nonselective cation current in muscarinic responses of canine colonic muscle. Am. J. Physiol. 265: C1463-C1471.

Liu, L.W.C., and Huizinga, J.D. 1993. Electrical coupling of circular muscle to longitudinal muscle and interstitial cells of Cajal in canine colon. J. Physiol. (London), 470: 445-461.

Liu, L.W.C., Thuneberg, L., and Huizinga, J.D. 1995. Cyclopiazonic acid, inhibiting the endoplasmic reticulum calcium pump, reduces the canine colon pacemaker frequency. J. Pharmacol. Exp. Ther. 275: 1058-1068.

Missiaen, L., Declerck, I., Droogmans, G., Plessers, L., DeSmedt, H., and Raeymaekers, L. 1990. Agonist-dependent $\mathrm{Ca}^{2+}$ and $\mathrm{Mn}^{2+}$ entry dependent on state of filling of $\mathrm{Ca}^{2+}$ stores in aortic smooth muscle cells of the rat. J. Physiol. (London), 427: 171-186.

Molleman, A., Nelemans, A., and Den Hertog, A. 1989. $\mathrm{P}_{2^{-}}$ purinoceptor-mediated membrane currents in $\mathrm{DDT}_{1}$ MF-2 smooth muscle cells. Eur. J. Pharmacol. 169: 167-174. 
Oike, M., Kitamura, K., and Kuriyama, H. 1993. Protein kinase C activates the non-selective cation channel in the rabbit portal vein. Pflueg. Arch. Eur. J. Physiol. 424: 159-164.

Ozaki, H., Zhang, L., Buxton, I.L., Sanders, K.M., and Publicover, N.G. 1992. Negative-feedback regulation of excitationcontraction coupling in gastric smooth muscle. Am. J. Physiol. 263: C1160-C1171.

Pacaud, P., and Bolton, T.B. 1991. Relation between muscarinic receptor cationic current and internal calcium in guinea-pig jejunal smooth muscle cells. J. Physiol. (London), 441: 477-499.

Randriamampita, C., and Tsien, R.Y. 1993. Emptying of intracellular $\mathrm{Ca}^{2+}$ stores releases a novel small messenger that stimulates $\mathrm{Ca}^{2+}$ influx. Nature (London), 364: 809-814.

Sawyer, G.W., and Ehlert, F.J. 1998. Contractile roles of the $\mathbf{M}_{2}$ and $\mathrm{M}_{3}$ muscarinic receptors in the guinea-pig colon. J. Pharmacol. Exp. Ther. 284: 269-277.

Shuttleworth, T.J., and Thompson, J.L. 1992. Modulation of inositol $(1,4,5)$ trisphosphate-sensitive calcium store content during continuous receptor activation and its effects on calcium entry. Cell Calcium, 13: 541-551.

Smith, T.K., Reed, J.B., and Sanders, K.M. 1987. Origin and prop- agation of electrical slow waves in circular muscle of canine proximal colon. Am. J. Physiol. 252: C215-C224.

Takai, Y., Awaya, S., and Takai, A. 1997. Activation of nonselective cation conductance by carbachol in freshly isolated bovine ciliary cells. Pflueg. Arch. Eur. J. Physiol. 433: 705-712.

Unno, T., Komori, S., and Ohashi, H. 1995. Inhibitory effect of muscarinic receptor activation on $\mathrm{Ca}^{2+}$ channel current in smooth muscle cells of guinea-pig ileum. J. Physiol. (London), 484: $567-581$.

Van Breemen, C., and Saida, K. 1989. Cellular mechanisms regulating $\left[\mathrm{Ca}^{2+}\right]_{\mathrm{i}}$ smooth muscle. Annu. Rev. Physiol. 51: 315-329.

Yabu, H., Obara, K., and Usuki, T. 1992. Calcium and potassium channel regulation by protein phosphorylation in smooth muscle cells of guinea pig taenia coli. Adv. Exp. Med. Biol. 311: 41-52.

Zhang, L.B., and Buxton, I.L. 1991. Muscarinic receptors in canine colonic circular smooth muscle. II. Signal transduction pathways. Mol. Pharmacol. 40: 952-959.

Zholos, A.V., and Bolton, T.B. 1997. Muscarinic receptor subtypes controlling the cationic current in guinea-pig ileal smooth muscle. Br. J. Pharmacol. 122: 885-893. 